\title{
The Effect of Storytelling Technique on Speaking Ability of Female Iranian Intermediate EFL Learners
}

\author{
Esmail Zare-Behtash \\ English Language Department, Chabahar Maritime University, Chabahar, Iran \\ E-mail: behtash@cmu.ac.ir \\ Amin Saed (Corresponding author) \\ English Language Department, Chabahar Maritime University, Chabahar, Iran \\ E-mail: Amin.saed@cmu.ac.ir \\ Fatemeh Sajjadi \\ E-mail: fatemehsajjadi21@yahoo.com
}

Received: 03-07-2015

Published: 01-01-2016
Accepted: 15-10-2015

doi:10.7575/aiac.ijalel.v.5n.1p.209
Advance Access Published: October 2015

URL: http://dx.doi.org/10.7575/aiac.ijalel.v.5n.1p.209

\begin{abstract}
The main purpose of the present quasi-experimental study is to investigate the effect of storytelling technique on writing ability of Iranian intermediate EFL learners. To this end, 40 female intermediate EFL learners with the age range of 1416 attending Chabahar Maritime University High School were initially selected. The homogeneity of their proficiency level was established via the administration of a TOEFL (the Paper-Based Test) proficiency test. Then they were randomly divided into two control and experimental groups. A speaking test was administered to female subjects of both groups at the beginning of the study. The experimental group used storytelling technique two times a week while the control group was not trained on this technique. At the end of the study, a speaking test was administered to all subjects for examining their ability in speaking skill. Independent sample t-test and paired sample t-test were performed for data analysis. The results showed that storytelling technique had a significant effect on improving the speaking ability of intermediate EFL learners.
\end{abstract}

Keywords: storytelling technique, speaking ability, EFL learners

\section{Introduction}

Speaking fluently and appropriately plays a critical role in learning a foreign language. A focus on speaking English as a Foreign or Second Language (EFL/ESL) is a major goal for language learners and teachers all over the world. Richards \& Renandya (2002) stated that speaking is a basic element of language proficiency and provides much of the basis for how well learners listen, write, and read. Wongsuwana (2006) argued that speaking skills can be taught and it is not related to the talent. In order to have fluent communication, having good language skills is considered to be very important and these are listening, speaking, reading and writing altogether. But among these skills, speaking is regarded essential for oral communication. Staab (1992) noted that in order to teach second language learners how to speak in the best way possible, some speaking activities are provided that can be applied both in ESL and EFL classroom settings. They include discussion, role play, simulation, information gap, brain storming, storytelling, interview, reporting, and playing cards (Staab, 1992). Storytelling is one of the activities that is regarded as the best choice which the researcher recommended for a better progress of the language learners. Telling a story or narration is a part of human beings' nature. This process can be viewed as a reflex, as most people apply it as a routine within the daily conversations both formally and informally. From this point of view, in the classroom context, it may be considered as a more reliable way of approaching language teaching. Haven (2000) identified storytelling to be powerful, motivating and effective, stating that "factual and conceptual information is learnt faster and better, and will be remembered longer, recalled more readily, applied more accurately when that information is delivered as a well-told story" (p. 75). Despite the works that have been done in the case of alleviating the problem of speaking properly, there still are learners who have serious difficulties in speaking English. The problem is that EFL learners lack the sufficient ability and the skills necessary to speak in a foreign language. Utilizing storytelling can be a significant learning tool in that it may assist teachers to organize their speaking training procedures. As a useful training strategy, it provides opportunities for students to listen and comprehend what they have listened. Furthermore, with the media of storytelling, students can express their thoughts and feelings, sort out what they have already learnt, and finally seek for new information. The present study was done to investigate the effect of storytelling on speaking ability of Iranian high school learners. In the present study, it was hypothesized that storytelling technique has no significant effect on speaking skill of the EFL learners. Therefore, it attempted to answer the following research question: 


\section{Speaking Skill and its Pedagogical Dimensions}

Learning a new language is a difficult and complicated task. When students learn a foreign language, they actually work on a new language system which is different from their own language. Moreover, for the purpose of being a skillful learner, they should learn how to use the principles of the new system appropriately. Speaking is one of the components of this system. Some researchers such as Khamkhien (2010) argued that speaking skill is certainly the most significant skill of any language and its mastery is the best achievement for speakers. When students tend to communicate orally, they require knowledge of different aspects of the new system including grammar, vocabulary, pronunciation, and so on (Khamkhien, 2010). Speaking is the process of building and sharing meaning through the use of verbal and non-verbal symbols, in a variety of contexts (Richards \& Renandya, 2002). It is one of the most significant language skills in all languages studies from mother language studies to foreign language studies. Doff (1995, p. 198) has viewed spoken language as a vital skill of acquiring a new language and accordingly acquiring its structures and vocabulary. As a result, teaching speaking skill becomes one of the main components of any language teaching class. The primary claim is the notion that it is a medium, which carries learners' communication goals; learning to understand and transferring the meaning, is what counts in learning another language. Osborn (2008) stated that language learners have different goals ranging from educational to non-educational goals to speak in a foreign language. Learners who learn EFL have few opportunities to speak English outside the classroom in the real world (Zhang, 2009). Motivation, communication, practice, relevance, instruction, performance are the basics for developing language skills (Lipman, 2003) in EFL educational context. If students are presented with the opportunity to make choices and decisions about what they do, they will be more motivated to engage with learning activities. In this vein, many activities can be done to develop well-organized speaking-centered programs in EFL contexts. For example, stories, anecdotes, jokes, talks, and commentaries that are used with one speaker can be used to improve the speaking ability of other peers. Byrne (1986) stated that "if teacher is telling a story or giving a talk to the class, he should try to be as spontaneous as possible" (p. 35). Functional speaking skills implies the fact that the teachers' instructional talk in the class affects how students learn both language and classroom daily affairs (Koshy, 2005). Establishing as much confidence and competence as possible in the learners improve their speaking abilities to a great extent. On the other hand, Patil (2008) ascertained that teachers should highlight learners' confidence to lower their anxiety and stress and to decline the fear of making errors. Moreover, according to Shumin (1997), there are several elements which are involved in developing an effective speaking ability. They include listening skills, sociocultural factors, affective factors, linguistic factors, and sociolinguistic competence such as grammatical, discourse, sociolinguistic, and strategic competence (Shumin, 1997).

\subsection{The Importance of Storytelling}

Narration is regarded as one of the issues which are mainly introduced in the field of literature. According to Fisher (1984), narration as an extended field covered different forms of rhetoric actions. Fisher (1984) defined narration as "a theory of symbolic actions - words and/or deeds - that have sequence and meaning for those who live, create, or interpret them" (p. 21). Maynard (2005) stated that stories are important to people, politics, and education. Different people in different ages tell stories in different ways to other people in other ages and make use of them for different purposes. For example, in young people's stories which they act out as they play, it can be seen that how they show people are related to one another, what their imagination about their future wishes and needs are, and how to behave. In the case of adult storytellers, they tend to tell, describe, hesitate, and recommend about the most influential values around the world. After all, passing on traditions and cultural heritage has always occurred through the telling of stories.

Storytelling is one of the speaking techniques which is usually used in teaching speaking skill. Students can briefly summarize a tale or story they heard from somebody beforehand, or they may create their own stories to tell their classmates. Story telling fosters creative thinking. It also helps students express ideas in the format of beginning, development, and ending, including the characters and setting a story has to have (Kayi, 2012). "Storytelling is a task shared by storyteller and story listeners, it is the interaction of the two that makes a story come to life" (Baker \& Greene, 1985, p. 28). According to their definition, the components of a story include storyteller, story listener, its topic, and authentic-based issues. Telling is the live person to person oral and physical presentation of a story to an audience. "Telling" involves direct contact between teller and listener. It mandates the direct presentation of the story by the teller. The teller's role is "to prepare and present the necessary language, vocalization and physically to effectively and efficiently communicate the images of a story" (Barzaq, 2009, p. 7). They concentrated on the role of speaker and listener. The teller focuses on the vital images, actions, characters, and events of a story in order to convey the right meaning to the story listener. The story in the listeners' minds is dependent upon the performance of the teller. This technique can help students "develop accurate inflections, consistent expressions in the English language and facial and body expressions” (Colon-Vila, 1997, p. 58).

\subsection{Storytelling and Language Skills}

A number of studies have shown that there is a close relationship between storytelling and four language skills of listening, speaking, reading, and writing. For instance, Farrell (1991) claims, "the many advantages that storytelling has for our young elementary students include reading motivation, and active listening comprehension, a modeling of oral language, bonding, providing a safe environment for oral and written language sharing" (p. 38). Due to the importance of language skills in the second language learning and teaching contexts, various studies have been done to develop various evidence-based approaches which help students to acquire language skills as easily as possible. Based on what Barton and Booth (1990) stated the process of combining language and thought to imagery is the essential component of oral and written language comprehension, language expression, and critical thinking. On the other hand, storytelling 
is seen as a means of providing opportunities for listening and reading comprehension (Applebee, 1978), increased language fluency, and increased vocabulary (Wongsuwana, 2006). Different scholars in their studies showed that selfconfident learners can orally present narratives and have a new experience via storytelling as a medium of language learning (Bloch, 2010; Davies, 2007; Fox, 1993). Hence, it can be concluded that storytelling has developed a strong relationship between listening and speaking skills (Meyer, 1995).

\subsection{Storytelling and Oral Language}

It is argued that storytelling models the final utilization of the oral language. Oral language, i.e., speaking skill, listening, and visualizing skills are developed accordingly. In other words, language learners use their imaginations while listening to or telling stories. There is an appropriate level of connection between storytelling and speaking skill. Storytelling technique can be used in teaching visualization: "Visualizing is as much a foundation for literacy as hearing voice in words: students must be able to see what the words say. Storytelling mentally stimulates students as they naturally begin to imagine and make sense of the story while they listen" (Farrell, 1991, p. 14). Television, animations, movies, videos, and films provide images, but orally presenting the stories by its very nature leads listeners to construct their own images. The utilization of oral storytelling with the use of visual aids in the classroom enables students to gain remarkable learning experiences. In fact, students learn about themselves and others. They easily express values and beliefs in an understandable way to their classmates via oral language (storytelling). Oral storytelling results into the imagination. "The ability to visualize, to create images in the mind is at the very heart of storytelling, not just for the listener, but also for the teller" (Cooper, Collins, \& Saxby, 1992, p. 9). This statement means that as storytelling is visualized, learners can reach its aims more easily. Underwood (1989) pointed out visual materials can useful and advantageous when the topic is not relevant to the learners' everyday life and real-life experiences. Visual materials pay significant attention to the learners and they then concentrate on the topic and it provides learners the opportunity to get close to the topic (Underwood, 1989).

\section{Method}

This research is a quantitative study as it was carried out to explore whether applying storytelling technique to Iranian intermediate EFL learners has any influence on improving their speaking skill or not. A pre-test/post-test design was assigned for the conduction of this research.

\subsection{Subjects}

All subjects of this study were Iranian female EFL learners with the age ranges of 14-16 and were native speakers of Persian who were participating in English classes of first grade of high school at Chabahar Maritime University High School in Chabahar, Iran. All subjects had the same amount of exposure to materials before the experiment and all of them had studied English in the same school. Therefore, they were judged to be almost at the same level of language proficiency, namely intermediate level of English proficiency, however, their level was established via implementing TOEFL proficiency test. They were 40 high school students who were divided into two groups: 20 in control group, 20 in experimental group.

\subsection{Instruments}

Before the initiation of the study, all subjects were given TOEFL the PBT (the Paper-Based Test) proficiency test to ensure their level as intermediate language learners. The second pre-test which learners participated in, was a speaking proficiency test on the same level of the students. it was used to make sure that all subjects were in the same level of speaking skill. Finally, at the end of instruction, all of the subjects in experimental and control groups were post-tested through another speaking proficiency test.

\subsection{Procedure}

This experimental study was conducted during three months on Tuesdays and Thursdays for first-grade female high school students. At the start of the study two pre-test were administered to all subjects. After making sure of the subjects' homogeneity as intermediate, they were divided into one control group and one experimental group. All students in each group received the same amount of materials but the technique of teaching in groups was different. Every session took about 90 minutes; nearly 40 to 50 minutes of every session was spent working on the current study. The experimental group worked on storytelling technique via movies while the control group experienced traditional methods for example Direct Method. The teacher used the subtitles of the movies to clarify the meaning of ambiguous words and the required grammar. The target words and grammars that might have facilitated subjects` speaking ability were discussed on movies with their definitions and sample sentences. The teacher explained the total meaning of the movie, if necessary, in this phase. It should be mentioned that the definitions and sample sentences were orally presented and nothing was written on the board during strategy instruction. After completing the course one post-test was given to students, which was a speaking test taken from the same book as used for pre-test. Independent sample ttest and paired sample t-test were used for data analysis.

\section{Results and Discussion}

The research question of this study dealt with investigating the effect of storytelling technique on speaking skill of Iranian high school EFL learners. It was hypothesized that storytelling technique has no significant effect on speaking skill of the EFL learners. At the beginning of the study, all subjects took TOEFL proficiency test to ensure they were intermediate EFL learners. The estimated language proficiency mean of all participants amounted to 435.57 which 
established them as intermediate learners. Then they were randomly assigned into two groups, one experimental and one control group.

Table 4.1 Results of TOEFL proficiency pre-test

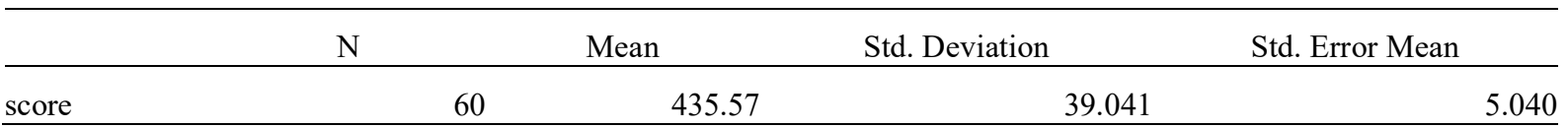

In the next stage, a speaking test was administered to all subjects as pre-test. It was used to make sure that there was no significant difference between experimental and control groups at the beginning of the study. Table 4.2 shows that the estimated speaking skill mean and standard deviation for the subjects in the experimental group amounted to 16.56 and 2.04 respectively and the evaluated mean and standard deviation for the subjects in the control group amounted to 16.83 and 2.19 respectively. An independent samples t-test was conducted to measure the difference in the mean scores of the pre-test mean. The reported $P$-value is .769 which is larger than .05 (See Table 4.2). Thus there was no significant difference between the experimental and control groups in terms of their speaking ability. In other words, the experimental and control groups were homogeneous and comparable at the beginning of the study.

Table 4.2 Results of speaking pre-test for the experimental and control groups

\begin{tabular}{lccccccc}
\hline Groups & $\begin{array}{c}\text { No. of } \\
\text { Students }\end{array}$ & Mean & SD & Std. Err & t & df & $\begin{array}{c}\text { Sig.(two- } \\
\text { tailed) }\end{array}$ \\
\hline Experimental & 20 & 15.3 & 2.04 & .40 & & & \\
\hline Control & 20 & 16.83 & 2.19 & .42 & .53 & 58 & .769 \\
\hline
\end{tabular}

A speaking test as post-test was administered to all subjects in experimental and control groups at the end of the treatment in order to measure their overall speaking achievement. To show the amount of enhancement of the experimental group, the performance of the subjects of this group at pre-test and post-test was compared. The comparison of the pre- and post-tests of the experimental group revealed a remarkable achievement in the speaking ability mean scores of the students. According to the pre-test and post-test mean values of 15.3 and 20.57 as well as a significant level of $p=(.000), p<.001$ (table 4.3), the experimental group has shown a great difference at the end of the experiment.

Table 4.3 Results of the speaking pre-test and post-test for the experimental group

\begin{tabular}{|c|c|c|c|c|c|c|c|}
\hline Experimental & $\begin{array}{c}\text { No. of } \\
\text { Students }\end{array}$ & Mean & SD & Std.Err & $\mathrm{t}$ & df & $\begin{array}{l}\text { Sig.(two- } \\
\text { tailed) }\end{array}$ \\
\hline Experimental & $\begin{array}{c}\text { No. of } \\
\text { Students }\end{array}$ & Mean & $\mathrm{SD}$ & Std.Err & $\mathrm{t}$ & df & $\begin{array}{l}\text { Sig.(two- } \\
\text { tailed) }\end{array}$ \\
\hline Pre-test & 20 & 15.3 & 2.04 & .40 & -12.27 & 58 & .000 \\
\hline Post-test & 20 & 20.57 & 2.42 & .51 & & & \\
\hline
\end{tabular}

On the other hand, to indicate the amount of progress of the control group, the performance of subjects in the pre-test and post-test was compared. The comparison of the pre- and post-tests of the control group illustrated achievement in speaking ability mean scores (Table 4.4) of the participants. The pre-test and post-test mean values of 16.83 and 17.99 show development in the participants' speaking ability and the level $p=.000,(p<.001)$ obtained through paired samples t-test indicates a statistical difference in speaking ability of the control group (Table 4.4). However, according to the mean difference $(-1.05)$ of the pre- and post-tests of this group which is less than one, it is clear that the control group's development compared to that of experimental group is very slight.

Table 4.4 Results of the speaking pre-test and post-test for the control group

\begin{tabular}{lccccccc}
\hline Control & $\begin{array}{c}\text { No. of } \\
\text { Students }\end{array}$ & Mean & SD & Std.Err & t & & $\begin{array}{c}\text { Sig.(two- } \\
\text { df }\end{array}$ \\
\hline Pre-test & 20 & 16.83 & 2.19 & .42 & & & \\
tailed)
\end{tabular}

Finally, an independent sample test was run to analyze all subjects' scores in the post-test. The estimated mean and standard deviation of the subjects' speaking skill in the experimental group amounted to 20.57 and 2.42 respectively and the estimated mean and standard deviation of subjects speaking skill in the control group amounted to 17.99 and 2.09(Table 4.5). An inspection of the mean scores showed that there was a considerable difference between the 
experimental and control groups in terms of overall speaking ability development. Moreover, the independent-samples t-test showed that this difference was statistically significant $(p=.000), p<0.05$. Therefore, the null hypothesis is rejected and the positive influence of storytelling technique on the subjects' speaking skill was confirmed (Table 4.5).

Table 4.5 Results of speaking post-test for the experimental and control groups

\begin{tabular}{lccccccc}
\hline Groups & $\begin{array}{c}\text { No. of } \\
\text { Students }\end{array}$ & Mean & SD & Std.Err & T & df & $\begin{array}{c}\text { Sig.(two- } \\
\text { tailed) }\end{array}$ \\
\hline Experimental & 20 & 20.57 & 2.42 & .51 & -7.48 & 58 & .000 \\
\hline Control & 20 & 17.99 & 2.09 & .39 & & & \\
\hline
\end{tabular}

The obtained results of this study correlated with the existing studies in the literature which portrayed that storytellingbased instruction could improve learners`speaking skill (Jianing, 2007; Scharle \& Szabó, 2000). Therefore, it is in common with the results of all studies indicating the usefulness of students participation in learning process of speaking skill. Due to the nature of this technique students are completely participated in classroom activities and indirectly or directly learn speaking skill.

The researchers, who support the effectiveness of storytelling technique, argued that this technique is better than the usual ways of teaching speaking. The reason is that storytelling technique requires students to engage in guided learning and problem solving and as a result improves their speaking skill. Those researchers, who advocate the use of storytelling technique in recommend that it is influential for language learners since it enable students to talk about different topics on their own words and make use of their previous when face some difficulties.

Contrary to the previous studies that had illustrated negative or no effect for storytelling technique on learners' improvement, the findings of the present research showed that storytelling group improved their speaking ability in speaking tests (pre and posttests) and this shows that storytelling technique have useful effects on learners' enhancement in the process of English language learning and their awareness of speaking skill. The results of this study showed that the experimental group outperformed control group in the pre and posttests. In other words, storytelling technique is more useful than more useful than usual approaches of teaching and learning the speaking skill of a foreign language.

\section{Conclusion}

Speaking skill is one of the most important skills in learning language, so various strategies and techniques are used in teaching speaking skill due to its importance. Storytelling-based instruction concentrates on involving learners and teachers in the learning process. The strong theoretical foundations of storytelling could have a remarkable effect on successful teaching and learning of speaking skill. Stories give relief from the routine and activate the memory and mind. Storytelling is a technique which worth pursuing in teaching English as a foreign language. Learners' ability to get the gist of the subjects, to recognize characters and to summarize what they have watched through the storytelling technique is shown the high degree of its potentiality. This research examined whether the storytelling technique was effective in improving speaking skills of Iranian first-grade high school learners. The main purpose of this study was to maximize students' speaking skill via storytelling technique. The results of the present study indicated that the Iranian EFL learners of English improved their speaking ability as a result of receiving storytelling-based instruction. These results emphasize the significance of training language learners in EFL settings where instruction through storytelling technique are the most significant way through which learners can promote their language proficiency.It can be concluded that regarding the technique under discussion the experimental group outperformed control group. It also should be stated that based on the statistical results, the degree of learners' involvement in using the storytelling technique is effective in learning speaking skill. It can be concluded that storytelling technique facilitates students' speaking skill. This research may be helpful to English language teachers who have some sorts of difficulty in teaching speaking skill to EFL/ESL learners. The study motivates teachers to work on speaking skill through the utilization of storytelling technique. The other advantage of the outcomes of this research for teachers is that it may give language teachers the insight that incorporating storytelling technique into language teaching process could be beneficial. It also can determine a new way for English teachers to direct their learners moving towards meaningful learning. This study examined students' performances in improving their speaking skill. In other studies also males could be involved and the differences between males and females' performances and attitudes could be investigated.

\section{References}

Alna, O. (1999). The importance of oral storytelling in literacy development. The Ohio Reading Teacher, 15-18.

Applebee, A. (1978). The child's concept of story. Illinois: University of Chicago Press.

Baker, R., \& Greene, M. (1985). Storytelling: Art and Technique. London: Longman.

Barton, B., \& Booth, D. (1990). Stories in the classroom. Portsmouth,NH: Heinemann.

Barzaq, M. (2009). Integrating Sequential Thinking Thought Teaching Stories in the Curriculum. Action Research.AlQattan Center for Educational Research and Development QCERD.

Bloch, J. (2010). Digital storytelling: The second language writing classroom. In Office of the chief information officer. Retrieved from ttp://digitalunion.osu.edu/2010/08/19/ digital-storytelling-the- second-language-writing-classroom/ 
Byrne, D. (1986). Teaching oral English. London: Longman.

Colon-Vila, A. (1997). Storytelling in an ESL classroom. Teaching PreK-8, 27(5), 58-59.

Cooper, P. J., Collins, R., \& Saxby, M. (1992). The Power of Story. Elbourne: MacMillan.

Davies, A. (2007). Storytelling in the classroom: enhancing traditional oral skills for teachers and pupils. London: Paul Chapman.

Doff, A. (1995). Teach English :A training course for teachers. Cambridge: Cambridge University Press.

Farrell, C. (1991). Storvtelling a Gujde for Teachers. New York: Scholastic.

Fisher, W. (1984). Narration as a Human Communication Paradigm: the Case of Public Moral Argument. Communication Monographs, 51, 1-23.

Fox, C. (1993). At the very edge of the forest: The influence of literature on storytelling by children. London: Casell.

Haven, F. K. (2000). Super simple storytelling: a can-do guide for every classroom, every day. Englewood, Colo: Teacher Ideas Press.

Jianing, X. (2007). Storytelling in the EFL Speaking Classroom. Internet TESL Journal,13(11), 1-8.

Kayi, H. (2012). Teaching speaking: Activities to promote speaking in a second language. The Internet TESL Journal. Retrieved June 20 2014, from http://unr.edu/homepage/hayriyek

Khamkhien, A. (2010). Teaching English Speaking and English Speaking Tests in the Thai Context: A Reflection from Thai Perspective. English Language Teaching Journal, 3(1), 184-200.

Koshy, V. (2005). Action research for improving practice: a practical guide (Vol. 11). London: SAGE.

Lipman, M. (2003). Thinking in education. Cambridge : Cambridge University Press. Maynard, B. (2005). The Importance of Story. Retrieved June 15 2014, from http://subversiveinfluence.com/2005/01/the-importance-of-story/

Meyer, R. J. (1995). Stories to teach and teaching story: The use of narrative in learning to teach. Language Arts, 72(4), 276-286.

Osborn, S. (2008). Public speaking guidebook. Boston: Pearson.

Patil, Z. N. (2008). Rethinking the objectives of teaching English in Asia. Asian EFL Journal, 10(4), 227-240.

Richards, J. C., \& Renandya, W. A. (2002). Methodology in language teaching: An anthology of current practice. Cambridge: Cambridge univrsity press.

Scharle, A., \& Szabó, A. (2000). Learner autonomy: A guide to developing learner responsibility. Cambridge: Cambridge University Press.

Shumin, K. (1997). Factors to consider: Developing adult EFL students speaking abilities. English Teaching Forum, 35(3), 8. Staab, c. (1992). oral language for today's classroom. Markam: Pippin Publishing Press.

Underwood, M. (1989). Teaching Listening. London: Longman.

Wongsuwana, T. (2006). Speech could be trained. Thailand Education Journal, 21, 44-50.

Zhang, Y. (2009). Reading to speak: Integrating oral communication skills. English Teaching Forum, 47(1), 32-34. 